\title{
Pengaruh Media Sosial dan Harga Terhadap Loyalitas Konsumen Pada Woodcraft "tanganketiga"
}

\author{
Winda Oktaviani \\ winda.oktaviani@uniku.ac.id
}

Fakultas Ekonomi Universitas Kuningan

\begin{abstract}
The object of this research is a creative inustry in manufacturing. This study aims to determine the response of consumers regarding social media, pricing and customer loyalty "tanganketiga", and to determine the effect of social media and the prices on consumer loyalty at Woodcraft "tanganketiga". Sample in this study consisted of 100 respondents. The data used in this study are primary and secondary data. This research is descriptive and explanatory by using correlation coefficient analysis and simultaneous test at a significance level of 5\%. These results indicate that social media has a strong relationship and significant impact on customer loyalty, in contrast to the price of which has a medium relationship and significant on customer loyalty.
\end{abstract}

Keywords: Social Media; Price, Consumer Loyalty.

\begin{abstract}
Abstrak
Objek penelitian ini adalah sebuah insdustri kreatif di bidang manufaktur. Penelitian ini bertujuan untuk mengetahui tanggapan konsumen mengenai media sosial, harga dan loyalitas konsumen "tanganketiga", dan untuk mengetahui pengaruh media sosial dan harga terhadap loyalitas konsumen pada Woodcraft "tanganketiga". Sample dalam penelitian ini terdiri dari 100 orang responden. Data yang digunakan dalam penelitian ini adalah data primer dan sekunder. Penelitian ini merupakan penelitian deskriptif dan eksplanatori dengan menggunakan metode analisis koefisien korelasi dan uji simultan pada tingkat signifikansi 5\%. Hasil penelitian ini menunjukan bahwa Media sosial memiliki hubungan yang kuat dan signifikan terhadap loyalitas konsumen, berbeda dengan harga yang memiliki hubungan sedang dan signifikan terhadap loyalitas konsumen.
\end{abstract}

Kata Kunci: Media Sosial; Harga, Loyalitas Konsumen.

\section{Pendahuluan}

Industri kreatif diproyeksikan menjadi sektor ekonomi dominan setelah perbankan dan industri pengolahan bagi negara-negara berkembang seperti Indonesia. Industri kreatif pada umumnya merupakan UMKM (Usaha Mikro Kecil dan Menengah) dengan modal usaha yang kecil, sehingga dalam memasarkan produknya masih dilakukan dengan cara tradisional seperti brosur atau WOM (Word Of Mouth) yaitu pemasaran dari mulut ke mulut dengan biaya yang murah atau bahkan tidak menggunakan alat promosi sama sekali. Dengan adanya perkembangan teknologi menjadikan internet sebagai bagian dari kehidupan masyarakat modern pada saat ini. Hal ini dikarenakan internet pada saat ini secara aktif menyediakan kebutuhan akan informasi mulai dari berita, hiburan, hingga ilmu pengetahuan. Oleh karena itu, perusahaan atau entrepreneur baik secara langsung atau tidak langsung harus mengikuti perkembangan jaman yang ada, salah satunya ialah dengan melakukan aktifitas-aktifitas menggunakan media sosial.

Dewasa ini banyak UMKM pelaku industri kreatif bahkan perusahaan besar yang menggunakan media sosial sebagai alat promosi, menyebarkan informasi yang berhubungan dengan aktifitas perusahaan, 
Indonesian Journal Of Strategic Management

Vol 3, Issue 2, Agustus 2020

dan customer service yang mampu menjawab kritik dan saran secara langsung. Penggunaan dan pemanfaatan media sosial yang dilakukan dengan tepat dapat meraih perhatian konsumen khususnya untuk menciptakan ketertarikan pada konsumen sehingga mempengaruhi keputusan pembelian mereka. Contohnya beberapa industri kreatif yang sukses berbisnis dengan melakukan pemanfaatan media sosial dan internet adalah merek makanan ringan Ma'icih, merek jam tangan Matoa, merek fesyen PSD dan masih banyak lagi.

Berdasarkan hasil survey yang dilakukan Pusat Kajian Komunikasi (PUSKAKOM) UI, pengguna internet Indonesia pada 2014 sudah mencapai angka 88,1 juta jika dibandingkan dengan jumlah penduduk Indonesia yang ada 252,4 juta maka dapat dikatakan bahwa penetrasi pengguna internet di Indonesia mencapai $34,9 \%$. Angka tersebut meningkat cukup banyak bila dibandingkan dengan tahun 2013 dimana penetrasi internet baru mencapai $28,6 \%$. Sebanyak $85 \%$ dari jumlah pengguna internet di Indonesia menggunakan perangkat seluler untuk berselancar di dunia maya. Tidak kurang dari $87 \%$ pengguna internet di Indonesia menggunakan sosial media dan $11 \%$ diantaranya sudah melakukan jual beli online.

Dengan peningkatan pengguna internet di Indonesia, didukung kemudahan memperoleh data dan akses internet serta dapat dijangkau masyarakat luas selain menjadi sarana promosi yang baik bagi pengusaha juga menjadi ancaman tersendiri karena akan menimbulkan persaingan yang ketat bagi banyak perusahaan yang bergerak dibidang usaha sejenis. Hal tersebut juga mampu mempengaruhi pendapatan secara langsung bagi perusahaan yang tidak mampu bersaing dan memanfaatkan teknologi dengan tepat. Jenis ekonomi kreatif dengan skala usaha kecil dan menengah rentan akan
p-ISSN 2614-5391, e-ISSN 2614-2406

https://journal.uniku.ac.id/index.php/ijsm

persaingan karena modalnya relatif kecil dan ijin usaha yang mudah.

Subsektor kerajinan merupakan salah satu bentuk dari industri kreatif yang memiliki laju pertumbuhan eksport paling tinggi dibandingkan yang lainnya. Subsektor kerajinan merupakan kegiatan kreatif yang berkaitan dengan kreasi, produksi, dan distribusi produk yang dibuat dan dihasilkan oleh tenaga pengrajin yang berawal dari desain awal sampai dengan proses penyelesaian produknya, antara lain meliputi barang kerajinan yang terbuat dari batu berharga, serat alam maupun buatan, kulit, rotan, bambu, kayu, logam (emas, perak, tembaga, perunggu, besi) kaca, porselin, kain, marmer, tanah liat dan kapur.

\section{Landasan Teori}

\section{Media Sosial}

Definisi media sosial dari Wikipedia, media sosial adalah sebuah media online dengan para penggunanya bisa dengan mudah berpartisipasi, berbagi, dan menciptakan isi meliputi : blog, social networking, wiki, forum, dan dunia maya. Blog, social networking, dan wiki merupakan bentuk media sosial yang paling umum digunakan oleh masyarakat diseluruh dunia.

Menurut Andreas Kaplan \& Michael Haenlein (2010:61), media sosial adalah sebagai sebuah kelompok aplikasi berbasis internet yang dibangun di atas dasar ideology dan teknologi Web 2.0, dan memungkinkan penciptaan dan pertukaran user generated content.

Menurut Mersey, Malthouse \& Calder (2010) dalam Kapoor \& Suman. International Research Journal of Management Sociology \& Humanity (2014), situs media sosial memberikan peluang bagi perusahaan untuk terlibat dan 
Indonesian Journal Of Strategic Management

Vol 3, Issue 2, Agustus 2020

berinteraksi dengan konsumen potensial, mendorong rasa keintiman hubungan pelanggan, dan membangun semua hubungan yang bermakna penting dengan konsumen terutama di lingkungan bisnis saat ini ketika loyalitas konsumen bisa lenyap akibat kesalahan kecil yang bisa langsung menjadi asosiasi buruk bagi produk, services, merek, atau bahkan perusahaan.

\section{Harga}

Harga yang merupakan satu-satunya unsur bauran pemasaran yang seringkali dijadikan sebagai bahan pertimbangan bagi konsumen dalam melakukan pembelian yang tidak bisa dikesampingkan oleh perusahaan.

Swastha, (2000) mendefinisikan harga sebagai sejumlah uang (ditambah beberapa produk) yang dibutuhkan untuk mendapatkan sejumlah kombinasi dari produk dan pelayanannya. Dari definisi diatas dapat diketahui bahwa harga yang dibayar oleh pembeli sudah termasuk layanan yang diberikan oleh penjual. Banyak perusahaan mengadakan pendekatan terhadap penentuan harga berdasarkan tujuan yang hendak dicapainya. Adapun tujuan tersebut dapat berupa meningkatkan penjualan, mempertahankan market share, mempertahankan stabilitas harga, mencapai laba maksimum dan sebagainya.

\section{Loyalitas Konsumen}

Perilaku setelah pembelian suatu produk/ jasa ditentukan oleh kepuasaan atau ketidakpuasaan akan suatu produk sebagai akhir dari proses penjualan.pembentukan sikap dan pola perilaku seorang konsumen terhadap pembelian dan penggunaan produk merupakan hasil dari pengalaman mereka sebelumnya.

Griffin(2008;5) memaparkan bahwa upaya untuk memperoleh kepuasan pelanggan telah berhasil mempengaruhi setiap pelanggan. Konsep loyalitas pelanggan lebih banyak dikaitkan dengan
p-ISSN 2614-5391, e-ISSN 2614-2406

https://journal.uniku.ac.id/index.php/ijsm

perilaku (behavior) dari pada sikap. Sikap seorang pelanggan terbentuk sebagai alat dari kontak langsung dengan objek sikap. Sikap positif konsumen dapat ditunjukan melalui setia kepada produk perusahaan dibanding kepada perusahaan lain. Sedangkan sikap negatif ditunjukan melalui berkata negatif tentang perusahaan, pindah kepada perusahaan lain, mengajukan tuntutan kepada perusahaan melalui pihak luar.

\section{Hipotesis}

1. Media Sosial berpengaruh terhadap Loyalitas Konsumen pada Woodcraft "tanganketiga"

2. Harga berpengaruh terhadap Loyalitas Konsumen pada Woodcraft "tanganketiga"

3. Media Sosial dan Harga berpengaruh secara simultan terhadap Loyalitas Konsumen pada Woodcraft "tanganketiga"

\section{Metode Penelitian}

\section{Jenis dan Sumber Data Penelitian}

Data yang digunakan dalam penelitian ini adalah data primer dan sekunder. Sumber data primer padapenelitian ini adalah Survei, observasi, dan eksperimen. Sumber data sekunder penelitian ini diperoleh dari majalah, situs internet, dan dari perusahaan Woodcraft "tanganketiga".

\section{Populasi dan Sampel}

Dalam penelitian ini yang menjadi populasi adalah pengguna media sosial yang pernah membeli produk "tanganketiga". Sampel yang diambil sebanyak 100 responden dan jumlah tersebut diperkirakan sudah dapat mewakili populasi.

\section{Tahapan Analisis}

Tahapan analisis untuk menguji hipotesis dalam penelitian ini digunakan uji asumsi klasik, untuk melihat apakah model regresi linear berganda layak atau tidak digunakan, juga dengan melakukan uji hipotesis yaitu analisis regresi data panel, 
Indonesian Journal Of Strategic Management

Vol 3, Issue 2, Agustus 2020

yang harus memenuhi kriteria yaitu, uji Ftest, uji T-test, dan uji $\mathrm{R}^{2}$.

Hasil dan Pembahasan Koefisien Korelasi

Untuk mengetahui adanya pengaruh antara Media Sosial (variabel $\mathrm{X}_{1}$ ) terhadap
p-ISSN 2614-5391, e-ISSN 2614-2406

https://journal.uniku.ac.id/index.php/ijsm

Loyalitas Konsumen (variabel Y) maka penulis menggunakan rumus korelasi Spearman dengan melakukan pengolahan data melalui SPSS 17.0. Berikut ini penjelasan untuk mengetahui kuat atau tidaknya korelasi antar variabel.

Tebel 1

Korelasi Variabel $X_{1}, X_{2}$ dan $Y$

Correlations

\begin{tabular}{|c|c|c|c|c|c|}
\hline & & & MediaSosial & Harga & Loyalitas \\
\hline \multirow[t]{3}{*}{ Spearman's rho } & MediaSosial & $\begin{array}{l}\text { Correlation Coefficient } \\
\text { Sig. (2-tailed) } \\
\mathrm{N}\end{array}$ & $\begin{array}{r}1.000 \\
100 \\
\end{array}$ & $\begin{array}{r}.604^{*} \\
.000 \\
100 \\
\end{array}$ & $\begin{array}{r}.636 \\
.00 \\
10 \\
\end{array}$ \\
\hline & Harga & $\begin{array}{l}\text { Correlation Coefficient } \\
\text { Sig. (2-tailed) } \\
\mathrm{N}\end{array}$ & $\begin{array}{r}.604^{*} \\
.000 \\
100\end{array}$ & $\begin{array}{r}1.000 \\
100\end{array}$ & $\begin{array}{r}.523 \\
.00 \\
100\end{array}$ \\
\hline & Loyalitas & $\begin{array}{l}\text { Correlation Coefficient } \\
\text { Sig. (2-tailed) } \\
\mathrm{N}\end{array}$ & $\begin{array}{r}.636^{*} \\
.000 \\
100\end{array}$ & $\begin{array}{r}.523^{*} \\
.000 \\
100\end{array}$ & 1.000 \\
\hline
\end{tabular}

${ }^{* *}$. Correlation is significant at the 0.01 level (2-tailed).

Sumber: Data SPSS yang telah diolah, 2016

\section{Analisis Koefisien Korelasi Media Sosial $\left(\mathbf{X}_{1}\right)$ \\ Berdasarkan perhitungan yang hasilnya} dapat dilihat pada tabel 4.17 menunjukkan bahwa korelasi antara Media Sosial dan Loyalitas Konsumen sebesar 0,636, maka dapat disimpulkan bahwa besarnya hubungan antara Media Sosial terhadap Loyalitas Konsumen menunjukkan hubungan yang kuat, karena nilai korelasi berada pada interval 0,600 sampai dengan 0,799 .

Untuk arah hubungan menunjukkan arah hubungan yang positif atau searah, artinya semakin baik promosi melalui media sosial maka Loyalitas Konsumen akan meningkat dan sebaliknya jika promosi melalui media sosial buruk maka Loyalitas Konsumen akan menurun.

\section{Analisis Koefisien Determinasi Media Sosial $\left(\mathbf{X}_{1}\right)$}

Untuk mengetahui berapa persen besarnya hubungan atau kontribusi variabel $\mathrm{X}_{1}$ (Media Sosial) dengan variabel $\mathrm{Y}$ (Loyalitas Konsumen), maka dapat dihitung koefisien determinasi dengan menggunakan rumus sebagai berikut :

$\mathrm{Kd}=\mathrm{r}_{\mathrm{s}}^{2} \times 100 \%$
$\mathrm{Kd}=(0,636)^{2} \times 100 \%$
$\mathrm{Kd}=0,404 \times 100 \%$
$\mathrm{Kd}=40,4 \%$

Berdasarkan perhitungan di atas, maka dapat disimpulkan bahwa besarnya korelasi 
Indonesian Journal Of Strategic Management

Vol 3, Issue 2, Agustus 2020

antara Media Sosial dengan Loyalitas Konsumen "tanganketiga" adalah sebesar 40,4\% sedangkan sisanya sebesar 59,6\% merupakan faktor lain seperti atribut produk, brand image dan lain lain diluar promosi melalui Media Sosial yang dilakukan oleh "tanganketiga".

\section{Koefisien Korelasi}

Untuk mengetahui adanya pengaruh antara Harga (variabel $\mathrm{X}_{2}$ ) terhadap Loyalitas Konsumen (variabel Y) maka penulis menggunakan rumus korelasi Spearman dengan melakukan pengolahan data melalui SPSS 17.0. Berikut ini penjelasan untuk mengetahui kuat atau tidaknya korelasi antar variabel.

\section{Analisis Koefisien Korelasi Harga $\left(\mathbf{X}_{2}\right)$}

Berdasarkan perhitungan yang hasilnya dapat dilihat pada tabel 4.17 menunjukkan bahwa korelasi antara Harga dan Loyalitas Konsumen sebesar 0,523, maka dapat disimpulkan bahwa besarnya hubungan antara Harga terhadap Loyalitas Konsumen menunjukkan hubungan yang sedang, karena

nilai korelasi berada pada interval 0,400 sampai dengan 0,599.

Untuk arah hubungan menunjukkan arah hubungan yang positif atau searah, artinya semakin baik penetapan harga produk maka Loyalitas Konsumen akan meningkat dan sebaliknya jika penetapan harga produk buruk maka Loyalitas Konsumen akan menurun.

\section{Analisis Koefisien Determinasi Korelasi Harga $\left(\mathbf{X}_{2}\right)$}

Untuk mengetahui berapa persen besarnya hubungan atau kontribusi variabel $\mathrm{X}_{2}$ (Harga) dengan variabel $\mathrm{Y}$ (Loyalitas Konsumen), maka dapat dihitung koefisien determinasi dengan menggunakan rumus sebagai berikut :

$\mathrm{Kd}=\mathrm{r}_{\mathrm{s}}^{2} \times 100 \%$

$\mathrm{Kd}=(0,523)^{2} \times 100 \%$

$\mathrm{Kd}=0,273 \times 100 \%$
p-ISSN 2614-5391, e-ISSN 2614-2406

https://journal.uniku.ac.id/index.php/ijsm

$\mathrm{Kd}=27,3 \%$

Berdasarkan perhitungan di atas, maka dapat disimpulkan bahwa besarnya korelasi antara penetapan Harga Produk dengan Loyalitas Konsumen "tanganketiga" adalah sebesar 27,3 \% sedangkan sisanya sebesar 72,6 \% merupakan faktor lain seperti atribut produk, brand image dan lain lain diluar penetapan harga yang dilakukan oleh "tanganketiga".

\section{Pengujian Hipotesis \\ Uji Parsial Koefisien Korelasi}

Untuk menguji apakah terdapat hubungan yang signifikan antara variabel $\mathrm{X}_{1}$ (Media Sosial) dan $\mathrm{X}_{2}$ (Harga) terhadap variabel $\mathrm{Y}$ (Loyalitas Konsumen), maka penulis melakukan pengujian, uji hipotesis secara parsial menggunakan koefisien korelasi Rank Spearman untuk menentukan apakah diterima atau ditolak variabel yang kita teliti. Adapun pengujian hipotesis dilakukan dengan langkah-langkah sebagai berikut:

$\mathrm{H} 1$ :

$\mathrm{H}_{0}: \mathrm{r} \leq 0$, media sosial tidak berpengaruh terhadap loyalitas konsumen produk

"tanganketiga"

$\mathrm{H} \alpha: \mathrm{r}>0$, artinya media sosial berpengaruh terhadap loyalitas konsumen produk "tanganketiga"

$\mathrm{H} 2$ :

$$
\begin{aligned}
& \mathrm{H}_{0}: \mathrm{r} \leq 0, \quad \text { harga tidak } \\
& \text { berpengaruh terhadap } \\
& \text { loyalitas konsumen } \\
& \text { produk } \\
& \text { "tanganketiga" } \\
& \mathrm{H} \alpha: \mathrm{r}>0, \text { artinya harga } \\
& \text { berpengaruh terhadap } \\
& \text { loyalitas konsumen } \\
& \text { produk } \\
& \text { "tanganketiga" }
\end{aligned}
$$


Indonesian Journal Of Strategic Management

Vol 3, Issue 2, Agustus 2020

Berdasarkan tabel maka dapat disimpulakan hasil hipotesis secara parsial adalah sebagai berikut:

1. Dari tabel terlihat bahwa hasil pengujian hipotesis peranan media sosial menunjukkan nilai sebesar 0,636 dengan taraf signifikansi 0,000. Taraf signifikansi sebesar $0,000<0,05$, yang berarti signigikan maka hipotesis dalam penelitian ini menerima $\mathrm{Ha}$ dan menolak Ho. Dengan demikian dapat diartikan bahwa hipotesis $\mathrm{H}_{1}$ diterima bahwa "Media Sosial berpengaruh secara signifikan terhadap Loyalitas konsumen produk tanganketiga".

2. Dari tabel terlihat bahwa hasil pengujian hipotesis peranan harga menunjukkan nilai sebesar 0,636 dengan taraf signifikansi 0,000 . Taraf signifikansi sebesar $0,000<$ 0,05 , yang berarti signigikan maka hipotesis dalam penelitian ini menerima Ha dan menolak Ho.
p-ISSN 2614-5391, e-ISSN 2614-2406

https://journal.uniku.ac.id/index.php/ijsm

Dengan demikian dapat diartikan bahwa hipotesis $\mathrm{H}_{2}$ diterima bahwa "Harga berpengaruh secara signifikan terhadap Loyalitas konsumen produk "tanganketiga".

\section{Uji Simultan (Uji F)}

Untuk menguji pengaruh variabel bebas secara bersama-sama diuji dengan menggunakan uji F. Hasil uji secara simultan dapat dilihat dengan dua cara. Cara pertama yaitu secara simultan variabel X1 dan X2 akan berpengaruh signifikan signifikan terhadap Variabel Y, apabila Sig $<0.05$. Hasil pada tabel ANOVA dibawah hasil Sig 0.00,yang berarti bahwa secara simultan Media Sosial dan Harga berpengaruh signifikan terhadap Loyalitas Konsumen. Cara kedua yaitu membandingkan nilai $\mathrm{F}_{\text {hitung }}$ dengan $\mathrm{F}_{\text {tabel, }}$ berpengaruh apabila $F_{\text {hitung }}>\mathrm{F}_{\text {tabel. }}$.

Tabel 2

Hasil Uji Simultan (Uji F)

ANOVA $^{\mathrm{b}}$

\begin{tabular}{|ll|r|r|r|r|r|}
\hline Model & & Sum of Squares & df & Mean Square & F & Sig. \\
\hline 1 & Regression & 326.135 & 2 & 163.068 & 56.470 & $.000^{\circ}$ \\
& Residual & 280.105 & 97 & 2.888 & & \\
Total & 606.240 & 99 & & & \\
\hline
\end{tabular}

a. Predictors: (Constant), Harga, MediaSosial

b. Dependent Variable: Loyalitas

Sumber: Data SPSS yang telah diolah, 2016

Pengujian pengaruh variabel bebas secara bersama-sama terhadap variabel terikatnya dilakukan dengan menggunakan uji F. Hasil perhitungan statistik pada tabel 4.18 menunjukkan nilai $F_{\text {hitung }} 56,47>F_{\text {tabel }}$ 3,09. Dengan menggunakan batas signifikansi 0,05 , maka diperoleh nilai signifikansi $0.000<0,05$. Dengan demikian variabel Media Sosial dan harga secara bersama-sama (simultan) mempunyai pengaruh yang signifikan terhadap Loyalitas Konsumen pada Woodcraft "tanganketiga". 


\section{Koefisien Determinasi $\left(\mathbf{R}^{2}\right)$}

Koefisien determinasi merupakan besaran yang menunjukkan besarnya variasi variabel dependen yang dapat dijelaskan oleh variable independennya. Dengan kata lain, koefisien determinasi ini digunakan untuk mengukur kemampuan seluruh variabel bebas dalam menjelaskan variabel terikat. Nilai koefisien determinasi ditentukan dengan nilai adjusted $R$ square sebagaimana dapat dilihat pada tabel berikut:

Tabel 3

\section{Koefisien Determinasi}

\begin{tabular}{|c|c|c|c|c|}
\hline \multicolumn{5}{|c|}{ Model Summary } \\
\hline Model & $\mathrm{R}$ & R Square & $\begin{array}{l}\text { Adjusted R } \\
\text { Square }\end{array}$ & $\begin{array}{l}\text { Std. Error of the } \\
\text { Estimate }\end{array}$ \\
\hline 1 & $.733^{\mathrm{a}}$ & .538 & .528 & $1.69 s$ \\
\hline
\end{tabular}

a. Predictors: (Constant), Harga, MediaSosial

Sumber: Data SPSS yang telah diolah, 2016

Berdasarkan hasil perhitungan dapat diketahui bahwa koefisien determinasi (adjusted $R^{2}$ ) yang diperoleh sebesar 0.538. Hal ini berarti bahwa kemampuan variabel $\mathrm{X}_{1}$ dan $\mathrm{X}_{2}$ dalam menjelaskan Variabel $\mathrm{Y}$ adalah sebesar 53,8\%. Sedangkan sisanya sebesar 46,2\% dijelaskan oleh variabel lain diluar variabel yang diteliti dalam penelitian ini seperti atribut produk, brand image, dan lain-lain.

\section{Kesimpulan dan Saran Kesimpulan}

1. Tanggapan responden terhadap promosi melalui Media Sosial "tanganketiga" dikatakan Baik oleh responden, hal ini terbukti dengan besarnya nilai rata-rata dari hasil keseluruhan mengenai Media Sosial yang penulis teliti yaitu sebesar 3,99 terdapat pada interval $3,40-4,19$ hal ini menunjukan bahwa unsur-unsur Media Sosial "tanganketiga" baik. Unsur Media Sosial tersebut meliputi Online Communities, Interaction, Sharing of Content, Accessibility, dan Credibility. Akan tetapi masih ada halhal yang perlu diperhatikan yaitu pada penyataan konten yang menarik memiliki nilai terendah yaitu sebesar 3,89 yang artinya konten pada media sosial "tanganketiga" dirasa kurang menarik bagi konsumen atau followers.

2. Tanggapan responden berikutnya mengenai Harga produk "tanganketiga", secara keseluruhan nilai rata-rata yang didapat terdapat pada interval antara 3,40 - 4,19 yang artinya masih dalam kategori baik. Tetapi nilai terendah diperoleh pada pernyataan mengenai harga produk yang sebanding dengan kualitas yang artinya kualitas produk "tanganketiga" masih dirasa kurang sebanding dengan harga yang ditawarkan.

3. Secara umum tanggapan responden terhadap loyalitas konsumen "tanganketiga" tinggi yang ditunjukan dengan nilai rata-rata dari hasil keseluruhan yaitu sebesar 3,81 berada pada interval 3,40 - 4,19 akantetapi pada pernyataan "Sebagai konsumen Produk "tanganketiga", saya tidak tertarik atau tidak berminat terhadap tawaran produk pesaing" memiliki nilai terendah yang artinya konsumen masih 
Indonesian Journal Of Strategic Management

Vol 3, Issue 2, Agustus 2020

bisa dengan mudah beralih ke produk pesaing.

4. Pengaruh Media Sosial terhadap Loyalitas Konsumen pada Woodcraft "tanganketiga" berdasarkan hasil perhitungan korelasi Rank Spearman diperoleh nilai rs sebesar 0,636 yang menunjukan arah hubungan yang kuat. Besarnya pengaruh Media Sosial terhadap Loyalitas Konsumen sebesar 40,4\% sedangkan sisanya merupakan faktor lain diluar penelitian. Hasil uji Hipotesis diperoleh taraf signifikansi $0,000<0,05$. Hal ini menunjukan bahwa Media Sosial berpengaruh secara signifikan terhadap Loyalitas Konsumen "tanganketiga".

5. Pengaruh Harga terhadap Loyalitas Konsumen pada Woodcraft "tanganketiga" berdasarkan hasil perhitungan korelasi Rank Spearman diperoleh nilai rs sebesar 0,523 yang menunjukan arah hubungan yang sedang. Besarnya pengaruh Harga terhadap Loyalitas Konsumen sebesar $27,3 \%$ sedangkan sisanya merupakan faktor lain diluar penelitian. Hasil uji Hipotesis diperoleh taraf signifikansi $0,000<0,05$. Hal ini menunjukan bahwa Harga berpengaruh secara signifikan terhadap Loyalitas Konsumen "tanganketiga".

6. Pengaruh Media Sosial dan Harga terhadap Loyalitas Konsumen berdasarkan hasil uji Hipotesis menggunakan perhitungan uji $\mathrm{F}$ (Simultan) diperoleh hasil $F_{\text {hitung }}>F_{\text {tabel }}$ $=56,47>3,09$. Hal ini menunjukkan bahwa variabel Media Sosial dan harga secara bersama-sama (Simultan) mempunyai pengaruh yang signifikan terhadap Loyalitas Konsumen pada Woodcraft "tanganketiga". Pada uji koefisien determinasi diperoleh hasil sebesar 0.538. Hal ini berarti bahwa kemampuan variabel $\mathrm{X}_{1}$ dan $\mathrm{X}_{2}$ dalam
p-ISSN 2614-5391, e-ISSN 2614-2406

https://journal.uniku.ac.id/index.php/ijsm

menjelaskan Variabel Y adalah sebesar $53,8 \%$. Sedangkan sisanya sebesar $46,2 \%$ dijelaskan oleh variabel lain diluar variabel yang diteliti dalam penelitian ini seperti atribut produk, brand image, dan lain-lain.

\section{Saran}

Setelah melakukan penelitian, pembahasan, dan analisis maka selanjutnya penulis ingin mengajukan beberapa saran yang kiranya dapat menjadi bahan pertimbangan dan masukkan bagi perusahaan yaitu sebagai berikut :

1. Walaupun secara keseluruhan promosi melalui Media sosial dan penerapan harga pada Woodcraft "tanganketiga" dinyatakan baik, tetapi hal tersebut harus tetap dipertahankan oleh perusahaan. Sedangkan unsur media sosial yang harus diperhatikan dan ditingkatkan lagi oleh perusahaan adalah mengenai konten-konten pada media sosial yang menarik karena konsumen bisa saja dibuat jenuh dengan konten serupa selama bertahun-tahun maka dari itu kontennya harus dibenahi dan diperbaharui misalnya dengan memberikan tips interior design atau cara-cara merawat produk agar tahan lama.

2. Dari segi harga, unsur harga yang sesuai dengan kualitasnya harus lebih diperhatikan lagi karena produk yang dibuat oleh "tanganketiga" menggunakan material bekas/sisa maka harus dilakukan penyesuaian harga dengan bahan bakunya karena meskipun secara unsur seni sebuah karya kerajinan memiliki nilai yang tinggi akan tetapi sebagian besar konsumen tidak paham dengan unsur seni yang dimaksud mereka hanya 
Indonesian Journal Of Strategic Management

Vol 3, Issue 2, Agustus 2020

membeli dan menggunakan produk yang menurut mereka menarik.

3. Karena kecendrungan konsumen berpindah kepada produk pesaing masih tinggi maka perusahaan disarankan untuk membangun brand imagenya dengan mengedepankan cirri khas dan keunikan dari perusahaan sehingga tidak didapatkan pada produk pesaing lainnya. Apabila brand image pada konsumen sudah kuat, maka penetapan harganya pun akan lebih mudah karena konsumen sudah loyal kepada perusahaan.

4. Hubungan antara Media Sosial dengan loyalitas pada perusahaan berdasarkan perhitungan memiliki hubungan yang kuat dan harus terus dipertahankan dengan modifikasi konten menjadi lebih menarik atau strategi lainnya yang bias diterapkan pada media sosial seperti mengadakan free gift atau free shipping sehingga menimbulkan ketertarikan tersendiri pada konsumen untuk menyimak timeline perusahaan.

5. Hubungan antara Harga dengan Loyalitas pada perusahaan berdasarkan perhitungan memiliki hubungan yang sedang. Hal ini berarti bahwa harga produk masih dirasa kurang seimbang baik dari segi kualitas, manfaat, keterjangkauan maupun harga yang bersaing dengan produk sejenis. Maka dari itu perusahaan harus pintar-pintar dalam menetapkan strategi harga terutama apabila perusahaan merupakan perusahaan yang baru berdiri. Menetapkan harga rendah diawal dan kemudian setelah brand image terbangun sedikit demi sedikit mulai menaikan harga menyesuaikan dengan brand image
p-ISSN 2614-5391, e-ISSN 2614-2406

https://journal.uniku.ac.id/index.php/ijsm

yang dibangun perusahaan sehingga bisa menjadi penentu harga dipasaran.

6. Secara bersama-sama Media Sosial memiliki pengaruh yang signifikan terhadap Loyalitas Konsumen. Dengan tampilan media sosial yang baik dan didukung strategi harga yang tepat akan memberikan kontribusi yang banyak dalam menciptakan loyalitas konsumen. Dengan membenahi media sosial dan strategi harga ditambah dengan service atau atribut produk yang sesuai dengan harapan konsumen maka kepuasan akan didapatkan yang berdampak langsung pada loyalitas konsumen.

\section{DAFTAR PUSTAKA}

Aaker, David A., 2006, Marketing Research. $7^{\text {th }}$ Edition. New York: John Wiley \& Son, Inc.

Adrian, Payne. 2000. Service Marketing Pemasaran Jasa. Yogyakarta : Andi.

Alma, Buchari. 2004. Manajemen Pemasaran dan Pamasaran Jasa. Edisi Revisi. Bandung : Alfabeta.

Bilson Simamora. 2002. Panduan Riset Perilaku Konsumen. Jakarta: PT. Gramedia Pustaka Utama.

Djaslim, Saladin. 2004. Manajemen Pemasaran-analisis Perencanaan, Pelaksanaan dan Pengendalian. Bandung : Linda Karya.

Emmy Indrayani, Hotniar Siringoringo dan Trini Saptariani, Impact of Price On Brand Loyalty Sensitivity, 2008. Gunadarma University. West Java, Indonesia.

Erdogmus, Irem Eren dan Cicek, Mesut. 2012. The Impact of Social Media Marketing on Brand Loyalty. Procedia - Social and Behavioral Sciences 58:1353-1360 
Indonesian Journal Of Strategic Management

Vol 3, Issue 2, Agustus 2020

Griffin, Jill. 2008. Customer Loyality. Edisi Revisi dan Terbaru. Jakarta : Erlangga.

Hurriyati, Ratih 2005. Bauran pemasaran dan loyalitas konsumen (dengan pemasaran efektif dan profitable). Bandung : Alfabeta.

Husein, Umar. 2008. Metode Riset Bisnis. Jakarta : PT. Gramedia Pustaka Utama.

J. Paul, Peter dan Garry, Olson , 2008. Consumer Behavior

Kaplan, Andreas M., Michael Haenlein. 2010. Users of the world, unite! The challenges and opportunities of Social Media. Business Horizons.

Kapoor, Mansi., Si, Suman. 2014. The Study The Growth of Brand Awareness Through Social Media Marketing and Understand the Lastest Trends Associated. International Research Journal of Management Sociology \& Humanity. http://www.irjmsh.com

Kotler, Philip. 2000. Manajemen Pemasaran. Jakarta : PT.Prenhallindo

Kotler, Philip and Kevin L. Keller. 2008. Manajemen Pemasaran. Jilid 1. Edisi 12. Alih Bahasa Benyamin Molan. Jakarta: Indeks.

------. 2008. Manajemen Pemasaran. Jilid

2. Edisi 12. Alih Bahasa Benyamin Molan. Jakarta: Indeks.

------- \&Armstrong. 2008. Prinsip-prinsip Pemasaran. Jilid 1. Jakarta : Erlangga.

Nadia Hanum Amiruddin. 2013. Price, Service Quality, and Customer Loyalty: A Case of Air Asia. Faculty of Business \& Entrepreneurship, University Malaysia Kelantan., Kelantan

Schiffman, Leon. G. dan Kanuk, Leslie. 2007. Perilaku Konsumen. Jakarta : Indeks.
p-ISSN 2614-5391, e-ISSN 2614-2406

https://journal.uniku.ac.id/index.php/ijsm

Simamora, Bilson. 2004. Riset Pemasaran. Cetakan Pertama. Jakarta : PT. Gramedia Pustaka Utama.

Singh, L., Jaffery, Z.A., Zaheeruddin, Z, dan Singh, R. 2010. Advances in Recent Technologies in Communication and Computing (ARTCom), International Conference

Stanton, William J, 2008. Fundamental of Marketing, Mc. Graw Hill Inc.

Sudjana, (2000). Statistik Untuk Ekonomi dan Niaga I. Bandung : Tarsito.

Sugiyono, 2008. Metode Penelitian Kuantitatif Kualitatif dan $R \& D$. Bandung : Alfabeta.

Suliyanto, 2005. Analisis Data dalam Aplikasi Pemasaran. Bogor : Ghalia Indonesia.

Swastha, B dan Irawan, H. 2000. Manajemen Pemasaran, Manajemen Pemasaran Modern, Yogyakarta: Penerbit Liberty

Taprial, Varinder \& Kanwar, Priya. 2011. Understanding Social Media [online]. Tersedia: http://bookboon.com/en/understandi ng-social-media-ebook

Ulber, Silalahi . 2009. Metode Penelitian Sosial. Bandung : PT. Refika Aditama

\section{Website:}

http://industrikreatif-depdag.blogspot.com/ http://www.kemenperin.go.id/ http://www.puskakomui.or.id/ http://www.inovasipintar.com http://www.wikipedia.org 